\title{
Microdialysis: Reducing the Delay in Detection of Shift in Molecular Composition a Laboratory Study
}

\section{Rauff-Mortensen Andreas ${ }^{1,2}$, Kirkegaard Hans ${ }^{2,3}$ and Birke-Sørensen Hanne ${ }^{1 *}$}

${ }^{1}$ Institute of Clinical Medicine, Aarhus University, Aarhus, Denmark

${ }^{2}$ Department of Anaesthesiology and Intensive Care Medicine, Aarhus University Hospital, Aarhus, Denmark

${ }^{3}$ Research Centre for Emergency Medicine, Aarhus University Hospital, Aarhus, Denmark

\begin{abstract}
Introduction: Microdialysis is one of the methods used clinically for the detection of ischemia. Although microdialysis is reliable, in most clinical settings there is a delay of 1-2 hours before the information is available.
\end{abstract}

Objective: The aim of this study was to evaluate whether an increase in the Microdialysis per fusion rate from 0.3 to 1.0 or $2.0 \mu \mathrm{l} / \mathrm{min}$ was capable of reducing the delay in the detection of a shift in molecular composition.

Methods and material: Microdialysis was performed in a container with 3 catheters per fused with $0.3,1.0$ and 2.0 $\mu \mathrm{l} / \mathrm{min}$. The molecular composition in the container regarding glucose and lactate was initially as follows: $\mathrm{C}_{\mathrm{Cucs}}=6.0$ $\mathrm{mmol} / \mathrm{L}$ and $C_{\text {Lactate }}=2 \mathrm{mmol} / \mathrm{L}$. At $T=90$ min the composition was changed to $C_{\text {Glucose }}=1 \mathrm{mmol} / \mathrm{L}$ and $C_{\text {Lactate }}=12 \mathrm{mmol} / \mathrm{L}$. Dialysates were harvested from the three catheters and were analysed regarding the concentration of glucose and lactate. For calculation of the relative recovery, samples were harvested directly from the liquid. The relative recovery and the delay before new steady state were calculated for each of the 3 catheters. The experiment was performed 8 times.

Results: A decrease in relative recovery was found with the higher perfusion rate. For glucose, the relative recovery was 100,88 , and $69 \%$ at perfusion rates of $0.3,1.0$ and $2.0 \mu \mathrm{l} / \mathrm{min}$. For lactate, the corresponding values were 103,93 , and $77 \%$. An increase in the lactate/glucose ratio was found with the higher perfusion rate. The delays in detection of shift in molecular concentration were found to be 60,20, and 10 minutes for catheters $0.3,1.0$ and 2.0, respectively.

Conclusion: Using microdialysis it is possible to significantly reduce the delay while still detecting a shift in the concentration of glucose and lactate when the perfusionrate is increased.

Keywords: Microdialysis; Monitoring; Ischemia delay; Laboratory study

Abbreviations: 0.3 Catheter: Catheter perfused with $0.3 \mu \mathrm{l} / \mathrm{min}$; 1.0 Catheter: Catheter perfused with $1.0 \mu \mathrm{l} / \mathrm{min} ; 2.0$ Catheter: Catheter perfused with $2.0 \mu \mathrm{l} / \mathrm{min}$; DS: Direct Samples; L/G ratio: Lactate/ Glucose Ratio; MD: Microdialysis; RR: Relative Recovery

\section{Introduction}

Ischemia is a known complication that can occur during and after several surgical procedures [1-5]. In cases of ischemia in an organ or a mass of tissue, timely detection is important if intervention is to be performed in due time. A number of invasive and non-invasive devices have been used for the detection of ischemia [6-10]. So far, no single monitoring method fulfils all the demands of clinical practice. The method must be harmless to the patient, rapid responsive, accurate, reliable, and easy to use for the hospital staff. Furthermore, it needs to have a high specificity and sensitivity. There does not seem to be any consensus in terms of which method to use in clinical practice [11]

Microdialysis is a micro invasive method used for the detection of ischemia and has been described in detail elsewhere [12,13]. The method has been proven useful and reliable for the detection of ischemia in neurosurgery, gastrointestinal surgery, reconstructive surgery, and transplantations [10,14-18].

In the standard clinical setting for gastrointestinal, reconstructive, and transplantation surgery, there is a diagnostic delay of 1-2 hours before the information regarding the molecular composition of the tissue becomes available. This delay is partly due to the perfusion rate of the catheter of $0.3 \mu \mathrm{l} / \mathrm{min}$. There are several reasons for the selection of this rate, with three of the most important being: (1) tradition (2) practical concerns and (3) the fact that the recovery of the molecules will be reduced if the flow rate increases [19]. As trends and relative values are almost as important as absolute values when monitoring ischemia, it might be possible to increase the flow rate without loss of sensitivity and specificity. If the delay can be reduced without a reduction in reliability, microdialysis might be the long-sought-after ideal monitoring method.

The aim of this study was in a laboratory model to evaluate whether an increase in the catheter perfusion rate from $0.3 \mu \mathrm{l} / \mathrm{min}$ to 1.0 or $2.0 \mu \mathrm{l} / \mathrm{min}$ was capable of reducing the delay in detection of a shift in molecular composition and still be reliable.

\section{Materials and Methods}

A bowl containing $450 \mathrm{ml}$ of saline, $11 \mathrm{ml}$ of glucose $50 \mathrm{mg} / \mathrm{ml}$, and $35 \mathrm{ml}$ of lactate Ringer $28 \mathrm{mmol} / \mathrm{l}$ was kept at room temperature, and the liquid was continuously mixed with a magnetic stirrer. Three microdialysis catheters (CMA 63, CMA Microdialysis, Stockholm, Sweden) were placed in the container with the microdialysis membrane below the surface. The three catheters were allocated to perfusion at 0.3 $\mu \mathrm{l} / \mathrm{min}(0.3), 1.0 \mu \mathrm{l} / \mathrm{min}(1.0)$ and $2.0 \mu \mathrm{l} / \mathrm{min}(2.0)$.

*Corresponding author: Hanne Birke-Sørensen, Brombaerhaven 78, 8520 Lystrup, Denmark, Tel: +45 2826 8609; E-mail: hanne.birke@ki.au.dk

Received November 29, 2013; Accepted November 29, 2013; Published December 23, 2013

Citation: Andreas RM, Hans K, Hanne BS (2013) Microdialysis: Reducing the Delay in Detection of Shift in Molecular Composition a Laboratory Study. J Transplant Technol Res 4: 126. doi:10.4172/2161-0991.1000126

Copyright: (C) 2013 Andreas RM, et al. This is an open-access article distributed under the terms of the Creative Commons Attribution License, which permits unrestricted use, distribution, and reproduction in any medium, provided the original author and source are credited. 
After 1.5 hours $(\mathrm{T}=90)$, a shift in molecular composition from simulated normal per fused tissue to ischemic tissue regarding glucose and lactate was obtained by adding $1250 \mathrm{ml}$ of isotonic saline and 1250 $\mathrm{ml}$ of Lactate Ringer $28 \mathrm{mmol} / \mathrm{ml}$ to the bowl. The intention was a shift in the concentrations of glucose from 6 to $1 \mathrm{mmol} / \mathrm{l}$ and of lactate from 2 to $12 \mathrm{mmol} / \mathrm{l}$.

Due to the time required for collection of the $10 \mu$ dialysate required for analyses, vials could be harvested at intervals of 30,10 , and 5 minutes from the 0.3 , the 1.0 , and the 2.0 microdialysis catheters, respectively. Dialysates were harvested from the three catheters as often as possible in the period just before and after the shift in molecular composition of the liquid (see Figure 1). For reference, $10 \mu \mathrm{l}$ of the liquid was harvested directly from the container at regular intervals (DS direct sample). Collection of dialysate and DS was continued until 1.5 hours after the shift in molecular composition. The dialysates were analysed with respect to the concentrations of glucose and lactate $\left(\mathrm{C}_{\text {Glucose }}\right.$ and $\left.\mathrm{C}_{\text {Lactate }}\right)$ at the CMA 600 analyzer (CMA Microdialysis, Stockholm, Sweden). This experiment was performed 8 times.

\section{Delay in detection of new values}

The delay in the detection of shift in molecular composition was defined as the time in minutes from $\mathrm{T}=90 \mathrm{~min}$ until the new steady state was reached for each of the three catheters. A new steady state was defined as the plateau at which the difference between two consecutive analyses was within the measuring accuracy of the CMA600 analyzer.

\section{Relative recovery}

The relative recovery (RR) is defined as the concentration of glucose or lactate in the dialysate expressed as a percentage of the concentration in the solution [19]. In this study, the concentration of glucose and lactate in the direct samples (DS) was used. Only the values measured during steady state were used in the calculation of RR.

\section{Statistics}

Statistical analyses were performed using Graph Pad Prism version 6 (Graph Pad Software, La Jolla, CA, USA). The results are expressed as median values with range unless otherwise stated. Comparison between groups was performed using a paired t-test. Level of significance was set at a $\mathrm{p}$-value $<0.05$.

\section{Results}

Analyses of glucose and lactate were conducted in all 8 experiments with no failures. Samples from catheters 1.0 and 2.0 showed significantly lower glucose and lactate concentrations during steady state compared to DS $(\mathrm{P}<0.0001)$. Samples from the 0.3 catheter were not significantly lower than the DS.

A decrease in relative recovery $(\mathrm{RR})$ was seen with higher perfusion rates (Table 1). For glucose, the RRs were $100 \%$ (96-107), 88\% (81$95)$, and $69 \%$ (60-81\%) for catheters $0.3,1.0$, and 2.0, respectively. For lactate, the corresponding RRs were 103\% (98-111\%), 93\% (87-101\%), and $77 \%(67-93 \%)$. For all three catheters, the RRs were significantly higher for lactate than for glucose.

The L/G ratio increased with higher flow-rates (Figure 2), and all $\mathrm{L} / \mathrm{G}$ ratios from the catheters were significantly higher than the $\mathrm{L} / \mathrm{G}$ ratio in Direct Sampling.

A significant reduction of delay in the detection of shift in molecular concentration was found with increasing perfusion rate. The delays were found to be 60,20 , and 10 minutes for catheters $0.3,1.0$, and 2.0 , respectively.

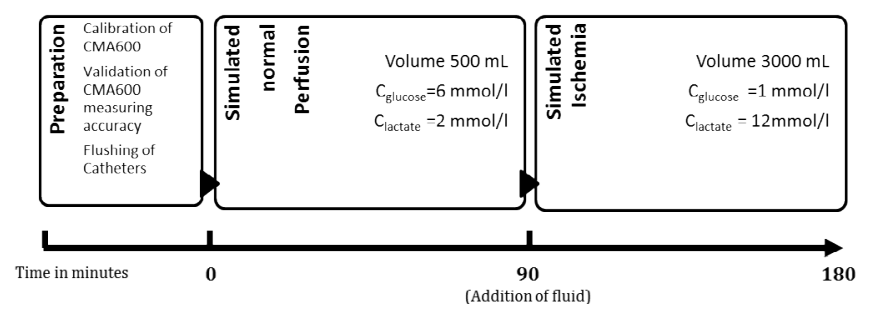

Figure 1: Flowchart of the laboratory study the timescale is in minutes.

\begin{tabular}{|c|c|c|c|c|}
\hline & Glucose/mM & Lactate/mM & RR Glucose/\% & RR Lactate/\% \\
\hline \multicolumn{5}{|l|}{$\begin{array}{l}\text { Simulating } \\
\text { normal perfusion }\end{array}$} \\
\hline Direct Sampling & $6.3(5.6 ; 6.8)$ & $1.8(1.8 ; 2.0)$ & & \\
\hline Catheter 0.3 & $6.4(5.7 ; 6.9)$ & $1.9(1.8 ; 2.0)$ & $101(96 ; 107)$ & $103(98 ; 111)$ \\
\hline Catheter 1.0 & $5.5(4.8 ; 5.9)$ & $1.7(1.6 ; 1.9)$ & $87(83 ; 95)$ & $92(87 ; 100)$ \\
\hline Catheter 2.0 & $4.3(3.8 ; 4.8)$ & $1.4(1.2 ; 1.5)$ & $69(61 ; 76)$ & $75(67 ; 93)$ \\
\hline \multicolumn{5}{|l|}{$\begin{array}{l}\text { Simulating } \\
\text { Ischemia }\end{array}$} \\
\hline Direct Sampling & $1.1(0.9 ; 1.4)$ & $10.8(10.0 ; 11.8)$ & & \\
\hline Catheter 0.3 & $1.1(0.9 ; 1.4)$ & $10.9(10.1 ; 12.1)$ & $99(96 ; 101)$ & $101(99 ; 104)$ \\
\hline Catheter 1.0 & $1.0(0.8 ; 1.2)$ & $10.2(9.7 ; 11.0)$ & $88(81 ; 95)$ & $94(91 ; 101)$ \\
\hline Catheter 2.0 & $0.7(0.6 ; 1.0)$ & $8.7(8.0 ; 9.2)$ & $67(60 ; 81)$ & $79(75 ; 89)$ \\
\hline
\end{tabular}

Table 1: Relative recovery (RR) and concentrations of glucose and lactate are given as mean values with total range. Only the values measured during steady state were used in the calculation of RR.

\section{L/G-ratio, Median}

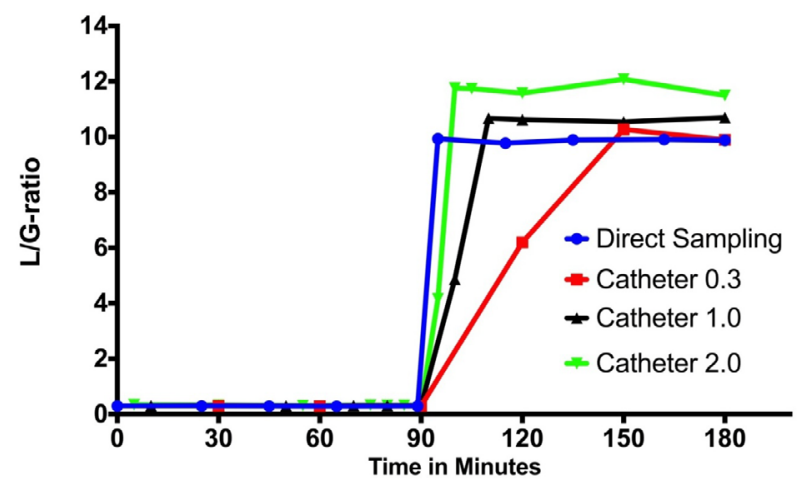

Figure 2: The calculated L/G-ratios from the $3 \mathrm{MD}$ catheters and from the direct samples during the two stable periods before and after the shift in the molecular composition of the fluid (at $\mathrm{T}=90$ minutes)

\section{Discussion}

The present laboratory study demonstrates how an increase in the perfusionrate of the microdialysis catheters can reduce the delay while still enabling the detection of a shift in concentrations of glucose and lactate.

Microdialysis as a monitoring method for the detection of ischemia would be more appealing with a diagnostic delay of 10-20 min instead of 1-2 hours [20]. Although the values of $\mathrm{C}_{\text {Glucose }}$ and $\mathrm{C}_{\text {Lactate }}$ obtained in catheters 1.0 and 2.0 were lower compared to the 0.3 catheter, due to a reduced $R R$, the trends were the same when the $\mathrm{C}_{\text {Glucose }}$ and the $\mathrm{C}_{\text {Lactate }}$ in the container were changed to ischemia simulation. It has been pointed out several times that trends are almost as important as absolute values when monitoring for the detection of ischemia [19]. 
For the L/G-ratio, a significant increase was seen in all three catheters after changes in molecular composition. As the reduction in RR with increasing perfusion rate was more pronounced for glucose than for lactate, there were consequently higher $\mathrm{L} / \mathrm{G}$ ratios with increasing perfusion rate. Ratios have, like trends, been shown to be important when monitoring for detection of ischemia, and a higher $\mathrm{L} / \mathrm{G}$ ratio with increasing perfusion rate might even ease the detection of a shift towards molecular composition mimicking ischemia.

Higher perfusion rates imply a shorter time for diffusion across the microdialysis membrane, giving an RR less than 100\% [21]. In accordance with this, we found an RR for glucose and lactate of 100 $103 \%$ for catheter $0.3,88-93 \%$ for catheter 1.0 , and $69-77 \%$ for catheter 2.0 .

Human studies have reported an RR of only $70 \%$ in brain tissue and $80-100 \%$ in muscle and adipose tissue at a flow-rate of $0.3 \mu \mathrm{l} /$ min. An increase in flow-rate to $1.0 \mu \mathrm{l} / \mathrm{min}$ resulted in an RR of only $30 \%$ in brain tissue $[22,23]$. As these RRs are much lower than the RR found in this laboratory study, it is obvious that our results cannot be transferred directly to clinical situations. In metabolic monitoring, there is a tradition of using the registered concentrations without adjustment according to RR [24]. This is partly due to the difficulties in determination of the RR in every case and partly due to the fact that the concentrations imply important information without adjustment. Furthermore it has been argued that the reduced RR slack the same undesirable effect on ratios, as the reduction has impact on the numerator as well as the denominator [24].

A dramatic reduction in the delay of the detection of ischemia by use of MD has been described, but so far only in studies where custommade tools have been used [25]. Whether a reduction can be obtained by using new systems and new equipment or by changing the standard use of existing tools does not matter. As time matters in case of postoperative ischemia in gastrointestinal surgery, reconstructive surgery, and transplantations a reduction in diagnostic delay is important. The goal is to reduce the delay without reducing the reliability. It is therefore important to investigate how the concentrations, the trends, and the ratios found in this laboratory experiment will change in situations more closely resembling clinical situations. In case the delay in detection of ischemia in a clinical setting can be reduced like in this laboratory study, it will mean a strong improvement of microdialysis as clinical monitoring method.

It is a weakness of this study that the shift in molecular composition happens over seconds rather than within several minutes to hours as in a clinical situation. Furthermore, it is a limitation that the sampling of vials in all eight experiments was uniformly synchronised with the shift in molecular composition ( $\mathrm{T}=90 \mathrm{~min}$ ). Random displacement of sampling in relation to the shift in composition might give different results regarding delay in detection, but should not have an impact on the RR.

Further research must address whether an increase in microdialysis perfusion rate can reduce the delay in the detection of ischemia in living tissue without reducing the specificity and sensitivity of the method. The next step should be an experimental study, evaluating the reduction in diagnostic delay to be obtained when monitoring by use of microdialysis with different perfusion rate after introduction of ischemia in isolated transfers under standardized conditions.

\section{Conclusion}

The present laboratory study demonstrates that through the use of microdialysis, it is possible to significantly reduce the delay in detection of a shift in the concentration of glucose and lactate when the perfusion rate is increased.

\section{References}

1. Krüger T, Conzelmann LO, Bonser RS, Borger MA, Czerny M, et al. (2012) Acute aortic dissection type A. Br J Surg 99: 1331-1344.

2. Dick F, Ricco JB, Davies AH, Cao P, Setacci C, et al (2011) Chapter VI: Followup after revascularisation. Eur J Vasc Endovasc Surg 42: S75-90.

3. Filsoufi F, Rahmanian PB, Castillo JG, Scurlock C, Legnani PE, et al. (2007) Predictors and outcome of gastrointestinal complications in patients undergoing cardiac surgery. Ann Surg 246: 323-329.

4. Mythen MG, Webb AR (1994) The role of gut mucosal hypoperfusion in the pathogenesis of post-operative organ dysfunction. Intensive Care Med 20: 203209.

5. Siniscalchi A, Piraccini E, Miklosova Z, Bagni A, D’Errico A, et al. (2007) Metabolic, coagulative, and hemodynamic changes during intestinal transplant: good predictors of postoperative damage? Transplantation 84: 346-350.

6. Pietak SP, Teasdale SJ (1979) Hemodynamic monitoring and care of the patient of high risk for anesthesia. Can Med Assoc J 121: 922-924, 926-8.

7. Neligan PC (1993) Monitoring techniques for the detection of flow failure in the postoperative period. Microsurgery 14: 162-164.

8. Cho BC, Shin DP, Byun JS, Park JW, Baik BS (2002) Monitoring flap for buried free tissue transfer: its importance and reliability. Plast Reconstr Surg 110: 1249-1258.

9. Hölzle F, Loeffelbein DJ, Nolte D, Wolff KD (2006) Free flap monitoring using simultaneous non-invasive laser Doppler flowmetry and tissue spectrophotometry. J Craniomaxillofac Surg 34: 25-33.

10. Keller AK, Jørgensen TM, Vittrup DM, Kjerkegaard UK, Jespersen B, et al (2013) Fast detection of renal ischemia in transplanted kidneys with delayed graft function-an experimental study. Transplantation 95: 275-279.

11. Smit JM, Zeebregts CJ, Acosta R, Werker PM (2010) Advancements in free flap monitoring in the last decade: a critical review. Plast Reconstr Surg 125 177-185.

12. Rojdmark J, Heden $P$, Ungerstedt U (1998) Microdialysis - A new technique fo free flap surveillance: Methodological description. Eur J Plast Surg 21: 344-8.

13. Keller A (2007) Noninvasive tissue oximetry for flap monitoring: An initial study J. Reconstr. Microsurg. 23: 189-97.

14. Bellander BM, Cantais E, Enblad $\mathrm{P}$, Hutchinson $\mathrm{P}$, Nordström $\mathrm{CH}$, et al. (2004) Consensus meeting on microdialysis in neurointensive care. Intensive Care Med 30: 2166-2169.

15. Sommer T (2005) Microdialysis of the bowel: the possibility of monitoring intestinal ischemia. Expert Rev Med Devices 2: 277-286.

16. Sorensen HB (2008) Free jejunal flaps can be monitored by use of microdialysis J Reconstr Microsurg 24: 443-448.

17. Kannerup AS, Funch-Jensen P, Grønbaek H, Jørgensen RL, Mortensen FV (2008) Metabolic changes in the pig liver during warm ischemia and reperfusion measured by microdialysis. J Gastrointest Surg 12: 319-326.

18. Setälä L, Papp A, Romppanen EL, Mustonen P, Berg L, et al. (2006) Microdialysis detects postoperative perfusion failure in microvascular flaps. $J$ Reconstr Microsurg 22: 87-96.

19. Ungerstedt U (1991) Microdialysis--principles and applications for studies in animals and man. J Intern Med 230: 365-373.

20. Birke-Sorensen H, Andersen NT (2010) Metabolic markers obtained by microdialysis can detect secondary intestinal ischemia: an experimental study of ischemia in porcine intestinal segments. World J Surg 34: 923-932.

21. Ungerstedt $U$ (1997) Microdialysis--a new technique for monitoring local tissue events in the clinic. Acta Anaesthesiol Scand Suppl 110: 123.

22. Rosdahl H, Hamrin K, Ungerstedt U, Henriksson J (1998) Metabolite levels in human skeletal muscle and adipose tissue studied with microdialysis at low perfusion flow. Am J Physiol 274: E936-945.

23. Hutchinson PJ, O'Connell MT, al-Rawi PG, Kett-White R, Gupta AK, et al 
Citation: Andreas RM, Hans K, Hanne BS (2013) Microdialysis: Reducing the Delay in Detection of Shift in Molecular Composition a Laboratory Study. J Transplant Technol Res 4: 126. doi:10.4172/2161-0991.1000126

(2002) Clinical cerebral microdialysis--determining the true extracellular concentration. Acta Neurochir Suppl 81: 359-362.

24. Ungerstedt $U$, Rostami E (2004) Microdialysis in neurointensive care. Curr Pharm Des 10: 2145-2152
25. Rogers ML, Brennan PA, Leong CL, Gowers SA, Aldridge T, et al. (2013) Online rapid sampling microdialysis (rsMD) using enzyme-based electroanalysis for dynamic detection of ischaemia during free flap reconstructive surgery. Anal Bioanal Chem 405: 3881-3888. 